\title{
1. Globalisation, the crisis and the state: introduction
}

\section{John H. Farrar and David G. Mayes}

The global financial crisis (GFC) has challenged much of conventional wisdom. Our conception of globalisation has been called into question. In particular, the Washington Consensus with its emphasis on deregulation and the shrinking of the state has been undermined. Instead, the importance of the state as regulator, investor and indeed economic saviour has been emphasised. We need then to readdress the relationship between globalisation, the crisis and the state, and this is the main objective of this book.

The purpose of this chapter is firstly to give an overview of the main issues arising from the relationship between globalisation, the GFC and the modern state, and secondly to outline the contents of the other chapters.

\subsection{GLOBALISATION}

'Globalisation' is a word whose usage dates back to the 1960s and connotes internationalisation and, to some extent, standardisation. It is mainly thought of in economic terms but can refer to social, political and other cultural matters. Some aspects of globalisation have been around for over 3000 years. The Silk Road enabled international trade to take place between East and West. A distinction is drawn between globalised localism and localised globalism. An example of the first would be the ubiquitous McDonald's, and an example of the second Rio Tinto's operations in Africa.

Professor Harry Arthurs, the distinguished Canadian academic, has referred to 'globalisation of the mind'. He argues that it 'involves a change in our social values and in our fundamental understandings about what role law does play and should play in society. Globalisation is, in other words, an ideology' (Arthurs, 2009, p. 632). He argues that beneath this ideology lies a bedrock assumption that governments which interfere with 
the free flow of goods, services, capital and information (but not people) impair their capacity to maintain a dynamic economy.

As a concept, globalisation filled a gap in the policies of the Clinton administration and was identified substantially with United States (US) hegemony and the Washington Consensus after the end of the Cold War. The result was that the role of the state, particularly in small countries, was constrained by membership of the global community, which reduced the ability to chose domestic policies in the face of standards of international agreements, increased competition and a degree of convergence mandated by international markets and credit rating agencies.

The complex processes currently summed up in the word 'globalisation' have their antecedents in imperialism, another ideology, and some writers see a conceptual overlap. Although there were earlier empires, the phrase is normally associated with the colonial expansion of European powers in the eighteenth and nineteenth centuries. Imperialism was regarded by Lenin as the highest stage of capitalism. He relied substantially on the book Imperialism by the English Fabian writer J.A. Hobson who had reported the Boer War for the Manchester Guardian. Hobson drew attention to the astonishing fact that the United Kingdom (UK) in the course of a single generation added an area of 4754000 square miles and a population estimated at 88 million to its domains. He also referred to the actions of other European powers and the late entry of the US. The second surprising fact was that the UK's imperial policy had no appreciable influence on the determination of its external trade. Indeed the greatest increase was with its industrial enemies and fellow colonisers. The import trade with the US alone was greater than that of the whole of the colonies. At the same time imperialism was an outlet for the migration of populations, but he thought this could be exaggerated. 'The new Empire is even more barren for settlement than for profitable trade'. How then was the UK induced to embark upon such an unsound business? Hobson thought that the business interests of the nation as a whole were subordinated to those of certain sectional interests, for private gain. It was good business for certain classes and certain trades, in particular the City of London and capital investment. 'The growing cosmopolitanisation of capital is the greatest economic change of this generation'. Every advanced industrial nation was tending to place a larger share of its capital outside the limits of its own political area in foreign countries or in colonies, and to draw a growing income from this source. The modern foreign policy of the UK was primarily a struggle for profitable markets of investment. The same was true of the other countries mentioned, including the US (Hobson, 1938 [1902]).

The US engaged in some of these activities in Puerto Rico, Hawaii and 
the Philippines, but operated under the illusion that it did not 'do empire'. This was a firm belief of Franklin D. Roosevelt who, as a Harvard student, had sponsored the Boer Relief Fund and had a deep antipathy to European colonialism, unlike his cousin and predecessor as President, Theodore Roosevelt. This antipathy strongly influenced his policies in the Second World War. Nevertheless the dominant role of the US in the Cold War after 1945, and particularly after 1990, has represented a hegemony resembling imperialism in some ways. It is this latter-day hegemony that has led to a US-dominated view of globalisation before the GFC. The US legitimated this by asserting that everyone was a winner from globalisation, whereas the GFC showed that there are winners and losers and that the West can end up on the losing side. This was obscured for a time by the rhetoric of G.W. Bush. The term 'new imperialism' has been used to describe the 'neo-con' approach of the G.W. Bush administration after 11 September 2001, and caused the US to lose legitimacy in the war on terror. It also contributed to the growth of an anti-globalisation movement.

An interesting recent development has been the communist literature in the West about 'The Rise of Chinese Imperialism':

China has turned the crisis of US and EU finance capital and the global recession into an opportunity to export its own finance capital and to establish imperialist spheres of influence. As a result, China is now entering directly into competition with the existing imperialist powers as an emerging imperialist rival, in particular posing a major challenge to the US, the UK, Germany and France and Japan. (Humanist Workers for Revolutionary Socialism, 2010)

The advantage of China over rivals is said to be that China is able to develop its imperialist character from its ability to use the Chinese people as a super-exploited proletariat. The Chinese government rejects this argument by maintaining that the collective welfare of the country is more important than individual citizens' rights. The party-controlled All-China Federation of Trade Unions is supposed to protect workers' rights, and independent trade unions are illegal. Reforms of workers' rights have been carried out but the enforcement is problematic. Nevertheless there has been dramatic improvement in the lives of hundreds of millions of Chinese. To do this in a large developing country with a population of over 1.3 billion is a massive and complex economic and political task. Jiang Zemin (2001) said in 2000:

To raise the living standard of the people constantly is the basic starting point and the final goal of all work of our Party. With the constant improvement of their livelihood the people will support the leadership of the Chinese 
Communist Party and the socialist system even more wholeheartedly, and devote themselves to the reform and opening-up and the modernization drive with even more confidence, and the ruling foundation of our party will be increasingly consolidated.

The GFC has undermined some of the Washington Consensus and led to a more multipolar world characterised by the G-20. Hence there is no longer one globalisation but several. Added to this is the reality that the world is no longer only a world of nation states and regional groupings of states, but also a world where multinational enterprises are often larger than many states. Some states now have sovereign wealth funds which are a puzzling hybrid that sometimes lack transparency.

The Seoul Consensus of 2010 put the emphasis on development. The six core principles of this Consensus are:

- focus on economic growth;

- global development partnership;

- global or regional systemic issues;

- private sector participation;

- complementarity; and

- outcome orientation.

The effect of recent events has been, firstly, to refute the determinist fallacy that was linked with US hegemony which involved confusing the causes of globalisation with its effects. Secondly, it marks a redefinition of North and South as centres of influence. We shall return to these points later but let us look at the GFC in more detail.

\subsection{THE GLOBAL FINANCIAL CRISIS}

The GFC arose out of the US subprime mortgage crisis. This social policy of the US was well intentioned but the dangers were underestimated by government and the financial sector. The risks of such loans were thought to be mitigated by the practice of securitisation. This took place at a time of extensive deregulation which had facilitated financial innovation and the use of complex derivative products. Again the risks were underestimated. The result led to both contagion and collapse of some US and UK financial institutions, as well as central bank and government intervention to prop up the system. These reactions were widely transmitted to other countries through the global financial and economic system. This experience has given rise to a reconsideration of the role of central banks and their relationship with governments. 
There was a need for action at an international as well as domestic level and this led to the formation of the G-20 and the reconstitution of the Financial Stability Forum as the Financial Stability Board (FSB), as well as action by the International Organization of Securities Commissions (IOSCO).

On an international level, the FSB fulfils a critical role. It has been positioned (by the G-20) to be at the centre of both international and national dialogue, and it provides a point of connection for governments and international bodies of experts (for example IOSCO), as well as institutions such as the International Monetary Fund (IMF) and the World Bank.

Since the beginning of 2010, the FSB has been very productive and has progressed significantly with the tasks imposed on it by the G-20. In April 2011, the FSB issued a progress report on the implementation of G-20 recommendations for strengthening financial stability. It reported the following:

- implementation of reforms to bank capital and liquidity standards;

- addressing systemically important financial institutions (SIFIs);

- regulatory measures for 'shadow banking';

- improving the over-the-counter (OTC) and commodity derivative markets;

- development of macroprudential frameworks and tools;

- progress towards convergence on strengthened accounting standards;

- strengthening adherence to international supervisory and regulatory standards; and

- FSB regional consultative groups to include FSB member and nonmember groups.

The FSB's April 2011 report also noted its progress on addressing the financial stability in emerging markets and developing economies, consumer finance protection, reducing reliance on credit rating agencies (CRAs), addressing data gaps, as well as market integrity issues. The FSB Chairman Mario Draghi suggested:

The ongoing international programme of financial reforms is strengthening the robustness of the global financial system. However, pockets of weakness in the banking system remain and sovereign and banking risks are closely intertwined in some countries.

While there is much more to be accomplished, the general direction appears to be set towards strengthening oversight and regulation. The 
measures relate primarily to ensuring that structure and operation of financial systems and financial firms are much less likely to be crisis-prone, but they also relate to ensuring that any problems that do occur, especially in large institutions, can be handled swiftly and with limited real consequences for the community at large.

In this context it is important to point out that the representatives of member countries at the G-20 are the finance ministers and the governors of central banks. Whereas central banks may increasingly be responsible for domestic financial stability, the GFC has highlighted the fact that national financial stability can no longer be the only focus and, because of globalisation, financial stability at international level should be ensured.

\subsection{THE ROLE OF THE STATE}

The traditional roles of the state have been:

- to maintain social order or declare war;

- to define property rights;

- to provide for administration of justice;

- to provide public goods;

- to regulate markets;

- to tax; and

- to redistribute wealth through welfare programmes (Farrar and Parson, 2012).

The growth of the modern welfare state resulted in an increased role for the state which has led to increased taxation.

The Washington Consensus, a product of US hegemony, and conceptions of globalisation advocated by bodies such as the IMF and the OECD before 2008, fostered the idea of a retreat of the state. This manifested itself in the following ways:

- privatisation;

- outsourcing;

- public-private partnerships;

- a race to the bottom by cutting taxes and deregulating; ${ }^{1}$

- the impacts of global finance on domestic economies;

- the impact on global systems of production;

- the bypassing of central governments;

- the transfer of policy-making in certain areas to supranational bodies; and 
- the emphasis on self-regulation, particularly in the field of corporate governmence.

The role of the state shifted to meta-governance of the economy in the sense of steering, resourcing and assuming accountability in state-owned enterprises and matters such as competition.

The Washington Consensus taken up by the IMF, World Bank and OECD led to a commercialisation of the state. New Zealand accepted this more than Australia did. A federal system tends to be more conservative. On the other hand, necessity has forced the New South Wales and Queensland State Governments to consider privatisation in often controversial circumstances. It was thought that greater efficiency and reduced cost would result from this commercialisation. At the same time, global systems of production and the power of the resources sector undermined the state's power to regulate the market.

In the early 1990s writers such as Kenichi Ohmae (1995) argued that nation states were becoming the local authorities of the global system. They were increasingly subject to the decisions and movement of international capital. This was a pro-business, anti-politics agenda and represented a temporary triumph of neoliberalism following on from the mixed experiences of monetarism in the 1980s.

In the decade since 11 September 2001, the West has been distracted by the war against terrorism and the costly invasions of Iraq and Afghanistan. Coupled with deregulation and tax reductions for the rich, the result has been an increase in debt, considerable errors of judgement and a dangerous state of affairs.

In the GFC, central banks and the state have had to intervene with the result that there has been quasi-nationalisation of some financial institutions and absorption of toxic debt by the state. At the same time there has been state capitalism in some parts of the world as well as the growth of sovereign wealth funds. These have the size to swing or stabilise markets yet lack transparency and may threaten national security. In spite of the resurgence of the state there has been a manifest need for international cooperation to deal with the crisis. The recent reforms of the US and UK have somewhat cut across development of international solutions.

Asian countries had learned the lessons of the Asian financial crisis and built up reserves as well as pursuing more cautious policies. It was the West which was affected most by the crisis which has led to a reconsideration of the relationship between China and the US, since China is now a major creditor of the US. Doubt has been cast on US hegemony and the Washington Consensus version of globalisation. At the same time the US still has military dominance. 
The main lessons that we can learn from the GFC are:

- no two crises are exactly alike;

- the first step in a crisis is to ensure stability of the system;

- regulators must be flexible to respond to an emerging crisis while recognising that they cannot manage it;

- regulators need to develop a global early warning system to identify asset bubbles and excesses in domestic and/or international markets and the systemic risk implications;

- there needs to be improved cross-border data sharing and cooperation;

- regulators must take into account the global nature of the present system and its complications;

- regulatory reform must not overreact or be overambitious;

- derivatives need special attention in terms of regulation, disclosure and risk management;

- the boundary of regulation and supervision needs to be pushed out to cover almost all of the financial sector including credit rating agencies; and

- the FSB as the place where all the regulators and other important role players meet has an important role as an international coordinating body. (Farrar et al., 2009, p. 37)

These lessons lead to the need for new institutions, or new functions for existing institutions, and a new approach to regulation.

The idea of a new Bretton Woods Agreement has not been pursued. Instead there has been a strengthening of existing institutions, notably the FSF (now the FSB) and IOSCO. There appears to be no departure from the principles of the system prior to the GFC, and no change to the conceptual framework or philosophy, but only improvements to existing infrastructure and legislative frameworks. The main themes of the new approach to regulation after the GFC appear to be:

- a greater focus on macro-prudential risks across the financial system which takes account of banks, shadow banks and private capital;

- greater emphasis on shared information on financial markets;

- a campaign to reduce regulatory arbitrage;

- some greater regulation of hedge funds;

- standardisation of credit derivatives markets and central clearing systems;

- agreed action against uncooperative tax havens;

- improved standards for valuation of financial instruments; and 
- more effective oversight of credit rating agencies. (Farrar et al., 2009, p. 38)

The so-called Washington Consensus contained a significant rhetorical element designed to combat the strong forces for personal and sectoral interests to appropriate the gains from liberalisation and inhibit their spread to the rest of the population. Since the 1950s it had been appreciated that a careful scheduling of the removal of barriers to economic development was needed, otherwise the forces of international competition could wipe out the fledgling sources of increasing value added in developing countries and emerging markets. Similarly, some intervention by the state is required to ensure an acceptable degree of redistribution of benefits across the population as a whole.

However, by the 1980s the view had altered and it was thought preferable to try to bring about change wherever it could be achieved, otherwise there would be little progress. In part it was felt that this would provide the pressure for other changes. This was very much the approach in New Zealand, for example. Liberalisation in product markets would lead to greater flexibility in labour markets and so on. ${ }^{2}$ Also barriers at the world level had fallen, as a result of over three decades of negotiation, and hence there was more global openness to adhere to. The richer countries undoubtedly made use of their bargaining power and it was only in the 1990s that the balance became more even with the result that there has been very limited progress on further agreement since then.

This change in view was typified by the advice given to the ex-communist countries, where gradualism was discouraged, in part for fear that there could be the ready means of return to an authoritarian regime. The success of some of the countries which ignored the advice, combined with the experience of the Asian crises, meant that the more extreme views were already outdated by the time of the GFC and what was required was the shock to bring the new orthodoxy into effect. The biggest feature tipping the balance was the continuing success of China. Much of the previous approach to policy was based on the appropriate response of a small country. China was large enough to affect the world on its own and hence could manage to maintain restrictions and absorb imbalances to an extent that would be largely impossible elsewhere, except India. Other countries, primarily in Asia, could therefore follow a similar course and opt out of some of the Western conventions.

At the same time, the maintenance of light regulation in the financial sector was largely an Anglo-Saxon phenomenon, not shared by continental Europe nor indeed elsewhere. The European Union (EU) with its quest for harmonisation has been a steady regulator, concerned to have 
comprehensive regulation rather than simply responding to market failure in the Anglo-Saxon tradition.

However, some aspects of US hegemony reflected through Washington consensus were more subtle though effective. The monopolisation of economic ideas was a case in point, where theory triumphed over pragmatism and simplified ideas based on unrealistic assumptions had considerable primacy. The example of dynamic stochastic general equilibrium models, without a role for money or credit, in the run up to the GFC in some central banks is a case in point. However, not all such errors were based on theory. In retrospect, one of the most important contributions to the GFC was the belief on the one hand that it was difficult to determine when financial bubbles were occurring rather than soundly based price growth, and on the other that the damage caused when bubbles burst could be limited by substantial rapid action by the authorities. This became known as the 'Greenspan standard' (Blinder and Reis, 2005) and contributed to easy money, overconfidence and a massive build-up of asset prices.

What the GFC did was provide the jolt which pushed countries and more importantly the global community into taking actions that they had been able to put off or ignore in the relatively benign economic circumstances of the late twentieth and early twenty-first centuries. The need for global cooperation to deal with global financial institutions was obvious. Disquiet with self-regulation, particularly regarding corporate governance, had led to a series of attempts at reform. In the UK, self-regulation of the financial sector ended in 1997 with the setting up of the Financial Services Authority - regrettably with flaws shown up by the GFC. Very little that the GFC threw up was new. Almost all of the issues took the form of problems that were well known in advance but thought to be of low probability despite their potential high impact. A large feature of the 'consensus' was simply that nothing had gone badly wrong for a long period of time and hence systems which were adequate in good times were not revealed as being disastrous in a crisis until the crisis struck.

\subsection{THE APPROACH IN THIS BOOK}

The subsequent chapters in the book approach the topic of globalisation, the GFC and the role of the state from a variety of perspectives. Chapter 2 by Margaret Wilson, for instance, looks at it from the point of view of a lawyer in parliament and in government and hence needing to debate and decide upon the legislative challenges that globalisation and the GFC have thrown down. This gives an excellent position from which to reflect on the changing role of the state. The chapter deals with New Zealand, 
which has implemented a huge programme of change, very much in line with the Washington Consensus since 1984. However, these changes were made not because of outside pressure, but from the conviction of the government of the day that the previous approach of substantial protection and government intervention in the economy was just not working. These changes were made, not by a government of the right, but by a Labour government. However, as the benefits of the rejuvenation of the economy did not spread to all parts of society and inequality increased, enthusiasm waned. Although the process picked up speed again with the election of a National Party government in 1990, Wilson shows how since 1993 there has been more questioning of globalisation.

In many respects New Zealand provided a test bed for the ideas and the early period was widely labelled the 'New Zealand experiment'. In addition to removing barriers to foreign trade and eliminating industry subsidies, many aspects of the economy were subject to 'light-touch' regulation. This did not include the labour market where the Employment Contracts Act replaced a strong role for trade unions. The GFC has shown that much of that light touch, certainly in respect of the finance company sector and also in aspects of corporate governance, has not worked. The tide has turned, with inter alia the extension of the powers of the Reserve Bank and the creation of the Financial Markets Authority.

Wilson provides a thorough review of the nature of the state in New Zealand, including the unusual complication of the Treaty of Waitangi and the relationship between Maori and the Crown. This special relationship can affect decisions such as privatisation and the sale of state assets. One feature of the New Zealand system which is of widespread interest is the new management of the public sector, whose impact is still being debated. However, perhaps the biggest challenge to globalisation has come simply through the democratic process. New Zealand has a rather participative democracy and with the introduction of proportional representation following a referendum it has become much more difficult to push policies through. While the balance between globalisation and social welfare has moved back somewhat towards the latter, New Zealand's scope for action has been reduced by the force of international law.

Wilson's very comprehensive and thought-provoking analysis provides the basis for the study of other countries. Laurence Boulle, in Chapter 3, shows how the GFC has affected the post-apartheid South African state. Recent decades have witnessed the increasing integration of Africa into the global economy and South Africa has been a major beneficiary but this sometimes clashes with the political processes and constitutional values. The construction of the post-apartheid state in itself has altered the system substantially, inter alia introducing more positive duties on the 
South African state to provide social services under the 1996 constitution. Not surprisingly as an emerging economy, South Africa has much more in common with the BRIC countries (Brazil, Russia, India and China) which it has now joined, with a much more substantial role for the state and more interventionist approach following what Boulle describes as the 'Seoul Consensus' for such countries. With the move to the G-20 as the grouping for dominating international cooperation, such countries are now able to have some real influence on international developments in a way that was not true before the GFC.

While Chapter 4 by Xiaohua Yang and Clyde Stoltenberg deals with China, it focuses on the changing relationship of Chinese multinationals and the state since the GFC. The advanced countries have been viewing with some concern the increasing involvement of Chinese companies with state backing in purchasing companies abroad while values are low as a result of the GFC, especially as these companies have benefited China's exchange rate management and limits to inward investment. The chapter documents the extent of their activities and explains that this is very much a deliberate strategy, focused on key industries, particularly where they are difficult to relocate. What these Chinese firms appear to be succeeding in is a form of state capitalism, where the firm is given sufficient independence to take commercial decisions but where the state provides the overall vision and assists financing and competitive advantage.

With an increasing focus on research and development (R\&D) and innovation, Chinese firms are acquiring more of the value-added and developing their competitive position. While the state is not loosening its hold over the system, arrangements are evolving and civil society arrangements are developing. Its sheer size gives China a powerful position that it is steadily developing both in the Asian region and in international organisations. As Yang and Stoltenberg conclude:

We expect that the future landscape for China and Chinese firms will be far from dull and unimaginative. While the role of the state will by no means recede and Chinese multinationals will become ever more active and visible on the global scene, other actors, such as civil organisations and associations, will inject new energy and visibility into the landscape.

A different facet of the challenges to the state comes from the EU where member countries have voluntarily agreed to delegate a number of key areas of decision-making, regulation and policy to the supranational level. The boundary is naturally contentious and the working relationship has obvious challenges. In Chapter 5, Jürgen Bröhmer describes the experience of Germany in the EU and its critical role in the euro crisis. Germany in particular has found itself having to take on a more major 
role in handling the consequences of problems in other member states than it wants, leading to a tension between narrow and broader interests in the successful development of the EU. Germany is, however, particularly interesting in this regard because of its federal structure. There are thus pressures on the nation state from both the EU and the Land levels. In some other EU member states, the subnational level sees the EU as a possible partner in gaining greater autonomy - Scotland and Catalonia for example.

These first few chapters in Part I, therefore, do not merely set up a framework for the analysis of how globalisation and the GFC have been affecting the role of the state, but they also illustrate the practice with respect to four countries. In Part II which follows, we look at the way in which the role of the state is changing in the realm of commercial activities. We have already noted the case of China. In Chapter 6 Tahnee Booth and Adrian Noon look at the case of Queensland and argue that its experience with state-owned companies has been good. Careful governance arrangements encourage efficient operation. International evidence suggests that for such efficient operation, companies need similar governance structures to the private sector, need to have to raise their own funds directly on the market and face competition in their activities. Such companies need to be clearly separate from direct influence from politicians but require a clear route of accountability and incentives for their performance. Booth and Noon argue that these companies have played a major role in the development of infrastructure in Queensland, which would not have been achieved through a purely private framework.

These characteristics for successful state-owned companies set out by Booth and Noon also apply to the companies set for partial privatisation in New Zealand, thus making the chance of gains from the change in ownership smaller. This forms the topic of the analysis by Chye-Ching Huang, Susan Watson and Jenny Chen of the case of New Zealand in Chapter 7. New Zealand is particularly interesting at present as the government has decided to privatise some of its key state-owned enterprises in the energy sector, and the national airline. These privatisations will be only partial, with the government retaining control. Furthermore the airline has already been privatised once before but had to be repurchased following disastrous losses.

The chapter considers the possible rationales for such privatisations and concludes that the case that can be made under most headings is rather weak, but so also is the case against such privatisations. Although the government made this an election issue in November 2011, the debate has not gone away and its principal coalition partner, the Maori party, is opposed to the sales. The government has a clear need to raise funding in 
the short run in order to halt the climbing debt that the GFC has caused; however it regards the sales as being of long-run benefit not just simply to the fiscal balance from having the companies better managed but also from better operation of capital markets and dynamic spillover effects. However, it is debatable whether the companies are inefficient despite their state ownership.

Chapter 8 by Michael Regan looks at a different way in which the state can interact with the private commercial sector by considering the growth of public-private partnerships (PPPs). While much of the literature on PPPs points out the problems which have occurred with them, Regan considers the successes. More importantly he evaluates their success not against some ideal but against the plausible alternatives, which would be sole state or private provision. In this light PPPs tend to show up rather better as all normal routes to designing, financing, constructing and running such projects have their drawbacks. Not all projects are suitable for PPP but where both parties cannot achieve their full objectives without the other a joint project stands a much greater chance of success. PPPs as a mere attempt to get round hard financial constraints on the public sector are unlikely to be particularly successful.

In Chapter 9 Graeme Hodge takes a much wider view of the role of the state as regulator, suggesting that we can view much of the way in which the government seeks to control the workings of the economy and society as 'regulatory governance'. Thus rather than providing some services itself it regulates how others do it. The range of regulation is considerable, including licensing, planning and environmental controls, a framework of corporate law, competition and restrictive practices regulation, procurement, PPP and rules on disclosure and intellectual property. All of this operates with the parallel framework of taxes, subsidies and services which can provide further influence and direction. All of this is a political activity. There is no single way of operating so the framework can evolve steadily, reflecting the views of different governments and popular pressure. The one feature which is painfully obvious is the enormous growth rate of this activity, with the pages of new regulation setting records each year despite occasional attempts to deregulate or, more frequently, reregulate.

Globalisation operates in this framework through a number of routes. There are all the examples of international agreement and the increasing openness of markets has to some extent altered the power of major players. Clearly there is substantial debate about the degree to which the state is the victim of market forces rather than the controller of them, but the idea of unfettered markets is not a description of reality despite the rhetoric.

Complementing the previous chapter, Hodge uses PPPs as his detailed example. Hodge is cautious about PPPs to say the least and is critical 
of many of the arrangements that have taken place in Victoria. Because of their contractual nature PPPs tend to offer little democratic recourse after signature. He is also cautious that the relationships are dressed up in words that sound good, such as 'partnership', without there being much in the way of tangible gains to back this up.

In Chapter 10 Louise Parsons considers the role of central banks and the state in dealing with the GFC. The rise of independent yet accountable central banks has been one of the notable features of the last 25 years. One of the means of assisting the achievement of price stability has been to elevate it above party politics and make it the goal of an institution that can be judged independently on its technical competence over the medium term. Leaving monetary policy as the direct responsibility of ministers runs the risk of it being subject to short-term considerations which would introduce just the volatility that policy seeks to avoid. Central banks have been very transparent in their actions and reasoning, so they can be judged. In the years up to the GFC these arrangements seemed to have been highly successful with the fall in inflation and much smoother economic development - famously labelled the 'great moderation' by the current Chairman of the Board of Governors of the Federal Reserve System, Ben Bernanke.

With the GFC this view has begun to look rather complacent as generally speaking central banks did not foresee the problems and still less did they take adequate action. The moderation has been replaced by the most substantial financial crisis since the 1930 s and the pendulum of political independence is likely to swing back - certainly from its most extreme example, the Eurosystem where the Governing Council has been able to decide itself what constitutes price stability, without a 'government' to decide on objectives beyond what is laid down in the Maastricht Treaty and maintained in the subsequent revisions.

The rise of these new bodies or the change in the independence of bodies derived from what would previously have been government departments is a pervasive phenomenon in recent years. Frank Vibert (2007) describes this as 'the rise of the unelected'. However, such bodies may actually increase the ability of both parliament and society at large to exert democratic control over the actions of government, as these bodies are separated out and can therefore be addressed directly, rather than having to wrap up the whole of a government's actions in a vote at a general election. Furthermore only a proportion of these agencies are executive bodies and others are monitors and supervisors of executive agencies and hence bring independent and objective powers of oversight, thereby easing the role of parliament as overseers of the conformity of government actions with parliamentary decisions. Similarly, openness and the requirement to 
consult locally may bring these bodies closer to popular control and not further as initial worries suggested.

The relation between the financial regulators and the GFC is developed further by David Mayes in Chapter 11 where he focuses on the issues behind the euro crisis and their implications for increased integration. The euro area was set up very much as a fair-weather system which worked well if it was not subject to severe adverse shocks. Although the euro area was far from an optimal currency area it was expected that it would slowly grow closer together and restructure steadily so that it was more able to withstand shocks - as illustrated by the case of Finland for example, which has changed markedly in the last 20 years and survived a heavy external shock in the early part of the GFC. The big mistake, however, was to bend the rules for entry and allow countries with high public debt ratios, such as Greece, to enter and then to fail to enforce the Stability and Growth Pact that should not merely have stopped indebtedness increasing but helped it fall to safer levels. The GFC has demonstrated the interconnectedness of economies particularly through the banking system. While other member states may be reluctant to lend to those in difficulty through fear of making losses, they are aware at the same time that a refusal to lend will result in bank failures and hence domestic losses through a different route. Hence the GFC is inevitably bringing countries closer together in Europe, through the agreements on much closer fiscal surveillance and the increased lending and the realisation that problems with the weaker affect all.

In the last chapter, Mohamed Ariff and John Farrar deal with the governance of sovereign wealth funds and foreign exchange reserves, their role in the GFC and the relationship with the modern state. Sovereign wealth funds highlight the tension between market capitalism and state capitalism and the contradictions in the latest permutations of globalisation. Countries that are less open are able to buy important stakes in the economies of the more open, which may lead to a response on the fairness of the international system. At the same time the build-up of foreign exchange reserves and the keeping of exchange rates artificially low, often by the same countries, are creating serious imbalances in the world, which are not merely inhibiting the recovery of some of the countries most affected by the GFC but offering a much greater chance of another crisis or the prolongation of the present crisis, as occurred in the 1930s.

As these chapters show, the power of the state has indeed changed substantially and continues to change, affected inter alia by the forces of globalisation. What the GFC has done by imposing a severe adverse shock is to expose the weaknesses of the changes that have taken place over several decades. In the future these weaknesses are likely to be addressed, 
probably with an increased role for the state and a more pragmatic approach to economic management, with greater emphasis on social and political concerns.

\section{NOTES}

1. In practice deregulation was selective and in general detailed regulation increased, particularly in the EU.

2. Not that all countries followed this precept. New Zealand's near neighbour Australia for example, decided to take the change more slowly and does not seem to have suffered as a result. More recently Finland decided that it needed the pressure of monetary union to get more flexible labour markets, while its neighbour Sweden with a similar economic position decided it should work on flexibility directly. Fifteen years later both countries have a similar performance. There does not appear to be a single recipe.

\section{REFERENCES}

Arthurs, H. (2009), 'Law and Learning in an Era of Globalisation', German Law Journal, 10, 629.

Blinder, Alan S. and Ricardo Reis (2005), Understanding the Greenspan Standard, accessed 15 March 2012 at http://www.kc.frb.org/publicat/sympos/2005/pdf/ blinderreis.paper.0804.pdf.

Farrar, John H. and Louise Parsons (2012), 'Globalisation, the Global Financial Crisis and the Reinvention of the State', Singapore Academy of Law Journal, 24, 367 .

Farrar, John H., Louise Parsons and Pieter I. Joubert (2009), 'The Development of an Appropriate Regulatory Response to the Global Financial Crisis', Bond Law Review, 21(3), 1.

FSB (2011), Financial Stability Board Press Release, Ref no:11/2011, 5 April, accessed September 2012 at http://www.financialstabilityboard.org/press/ pr_110405.pdf.

Hobson, John (1938 [1902]), Imperialism, A Study, 3rd edn, ed. John Atkinson, London: George Allen \& Unwin.

Humanist Workers for Revolutionary Socialism (2010), 'The Rise of Chinese Imperialism - How it has Exacerbated the Decay of World Capitalism and its Implications for the Class Struggle Today', accessed 9 March 2010 at http:// www.humanistsforrevolutionarysocialism.org/Publications/China_Pamphlet. pdf.

Jiang, Zemin (2001), On the Three Represents, Beijing: Foreign Languages Press.

Ohmae, Kenichi (1995), The End of the Nation State - The Rise of Regional Economies, New York: Harper Collins Publishers.

Vibert, F. (2007), The Rise of the Unelected: Democracy and the New Separation of Powers, Cambridge: Cambridge University Press. 
John H. Farrar and David G. Mayes - 9781781009437 Downloaded from PubFactory at 04/26/2023 09:05:11AM 